\title{
Soil Fungistasis: Role of Spore Exudates in the Inhibition of Nutrient-independent Propagules
}

\author{
By P. R. BRISTOW* AND J. L. LOCKWOOD \\ Department of Botany and Plant Pathology, Michigan State University, \\ East Lansing, Michigan 48824, U.S.A.
}

(Received 3I January 1975; revised I April 1975)

\begin{abstract}
SUMMARY
Suppression of germination of conidia of Cochliobolus victoriae was similar during incubation on sand being leached with water and on sand leached with salt solutions. Conidia of $C$. victoriae, Thielaviopsis basicola and Curvularia lunata, and sclerotia of Sclerotium cepivorum, exuded more ${ }^{14} \mathrm{C}$ label during leaching with phosphate buffer than on buffer-saturated sand without leaching. Conidia of $C$. victoriae and Cochliobolus sativus became dependent upon exogenous nutrients after 7 days' incubation on soil or leached sand. Decreased viability followed the loss of nutrient independence. Germination of $C$. victoriae and $C u$. lunata was stimulated when they were leached with exudate from spores of either fungus, or by a dilute nutrient solution simulating natural exudate. Conidia rendered nutrient-dependent by leaching, germinated and accumulated radioactivity when incubated on exudate from ${ }^{14} \mathrm{C}$-labelled spores. Nutrient-independent spores exude non-specific energyrich nutrients which may be rendered unavailable to the spores by microbial activity in soil, resulting in fungistasis.
\end{abstract}

\section{INTRODUCTION}

The failure of many fungal propagules to germinate in soil has been attributed to insufficient endogenous nutrient reserves and a nutritionally deprived soil environment, which is maintained by microbial competition (Ko \& Lockwood, 1967; Yoder \& Lockwood, 1973). Certain fungal propagules, however, contain sufficient energy reserves to germinate readily in glass-distilled water, but fail to do so in soil (Ko \& Lockwood, 1967; Emmatty \& Green, 1969; Hsu \& Lockwood, 1973). Germination of such nutrient-independent, yet fungistasissensitive, propagules is also suppressed during incubation on a bed of sand leached with water or phosphate buffer (Hsu \& Lockwood, 1973). This treatment imposes upon the propagule a steepened nutrient depletion gradient, and is designed to copy the microbial energy depletion sink in soil. Lingappa \& Lockwood (1964) demonstrated that nutrients exuded from propagules were rapidly utilized by soil microbes, and that when conidia of Cochliobolus victoriae and Glomerella cingulata were incubated with bacteria or actinomycetes their germination was suppressed. They proposed that microbial utilization of the exuded nutrients resulted in fungistasis, as the suppression of germination was not accompanied by the production of detectable inhibitory materials.

This research examined the effect of the leaching model system on exudation by nutrientindependent propagules and the significance of exudates in their germination.

\footnotetext{
* Present address: Department of Plant Pathology, University of Missouri, Columbia, Missouri 6520I, U.S.A.
} 


\section{METHODS}

Fungal propagules. Cochliobus victoriae and C. sativus were cultured in $25 \mathrm{ml}$ Fries No. 3 basal medium (Pringle $\&$ Scheffer, 1963) with glucose substituted for sucrose. Conidia were produced by transferring 5- to 7-day-old shaken cultures to filter paper (Lukens, I960). Thielaviopsis basicola and Sclerotium cepivorum were cultured on potato-dextrose agar (PDA), Curvularia lunata was maintained on V-8 juice agar, containing (per litre): V-8 juice (Campbell Soup Co.), $200 \mathrm{ml} ; \mathrm{CaCO}_{3}, 2.0 \mathrm{~g}$; agar, $20.0 \mathrm{~g}$. Four- to six-week-old cultures were irrigated with glass-distilled water, and the resulting conidial suspensions.washed three times in glass-distilled water by centrifugation at $2{ }^{\circ} \mathrm{C}$. Sclerotia of $S$. cepivorum were produced by inoculating the surface of PDA plates covered with cellophane. After 4 to 6 weeks the sclerotia were collected from the cellophane, and then treated for I $\min$ in $I \%(w / v)$ sodium hypochlorite solution to kill adhering hyphae before being washed. Conidia of $C$. victoriae and C. sativus were sometimes collected with a cyclone spore collector or by adherence to a Nuclepore (polycarbonate) membrane filter (General Electric Corp., Pleasantville, California, U.S.A.), pore size $0.4 \mu \mathrm{m}$, passed over dry filter paper cultures. Such conidia were not washed. Conidia of $C$. victoriae, $C$. sativus and $C u$. lunata were capable of germinating without exogenous nutrients, whereas those of $T$. basicola were nutrient-dependent.

Fungal propagules labelled with ${ }^{14} \mathrm{C}$ were produced on media amended with the following amounts of $\left[{ }^{14} \mathrm{C}\right]$ glucose (specific activity $50 \mathrm{mCi} / \mathrm{mmol}$ ): Fries No. 3 basal medium, I $\mu \mathrm{Ci} / \mathrm{ml}$; PDA and V-8 juice agar, $25 \mu \mathrm{Ci} /$ plate.

Spore germination assays. Conover loam soil (50 g) (Steiner \& Lockwood, 1969), previously sieved and air-dried, was re-moistened to about $27 \%(\mathrm{w} / \mathrm{w})$ moisture, placed in a Petri dish $(90 \times$ I $5 \mathrm{~mm})$, and the surface smoothed. Soil plates were incubated for $24 \mathrm{~h}$ before use. A system was used which attempts to provide a nutrient sink similar to the microbial nutrient sink of natural soil, through aqueous leaching of a bed of $100 \mathrm{ml}$ sand bearing the propagules on membrane filters (Hsu \& Lockwood, 1973). The volume of water held by the sand bed at saturation was $33 \mathrm{ml}$. The flow rate of the aqueous media through the sand (20 to $80 \mathrm{ml} / \mathrm{h}$ ) was metered with a peristaltic pump (Manostat Corp., New York, N.Y., U.S.A.). Acid-washed silica sand saturated with the same solution provided a nonleaching control for the model system. The following media were used: glass-distilled water; buffer solution (0.025 M-potassium phosphate, $\mathrm{pH} 7.0)$; Pfeffer's solution (per litre: $\mathrm{Ca}\left(\mathrm{NO}_{3}\right)_{2}, 0.8 \mathrm{~g} ; \mathrm{MgSO}_{4} .7 \mathrm{H}_{2} \mathrm{O}, 0.2 \mathrm{~g} ; \mathrm{KNO}_{3}, 0.2 \mathrm{~g} ; \mathrm{KCl}, 0.1 \mathrm{~g} ; \mathrm{K}_{2} \mathrm{HPO}_{4}, 0.2 \mathrm{~g}$ ); spore exudate; a dilute nutrient solution of glucose and casein hydrolystate; and subsoil extract. Subsoil extract was used to provide a soil extract essentially free of energy sources (Steiner \& Lockwood, 1969). It was prepared by stirring I kg subsoil, collected I $\mathrm{m}$ deep below Conover loam, in $\mathrm{r} \cdot 01$ glass-distilled water for $30 \mathrm{~min}$, then clarifying by passage through Whatman No. I filter paper and sterilizing by membrane filtration.

Membrane filters bearing the conidia were incubated in the leaching system, on saturated sand or on soil at $25 \pm 2{ }^{\circ} \mathrm{C}$. Following incubation, membranes were stained with phenolic rose bengal, then de-stained with water. The membranes were air-dried, mounted on glass slides, then dissolved in chloroform to render them transparent. Spores with germ tubes equal in length to the width of the spore were considered germinated. Germination counts were made of 200 spores on each of two membranes.

Spore exudates. Conidia $\left(5 \times \mathrm{I}^{3}\right.$ to $\left.70 \times 10^{3} / \mathrm{ml}\right)$ were suspended in 0.5 to 11 distilled water and incubated at $25 \pm 2{ }^{\circ} \mathrm{C}$ with stirring for a time less than that required for germination. The exudate was collected and sterilized by membrane filtration. Half the exudate was vacuum-dried, then redissolved in $10 \mathrm{ml}$ of glass-distilled water for nutrient analysis. 
The remainder was used in germination experiments. Carbohydrates, glucose and amino acids in the concentrated exudate were measured by the anthrone, Glucostat (Worthington Biochemicals Corp., Freehold, New Jersey, U.S.A.) and ninhydrin reagents, respectively. Radioactive exudate from $C$. victoriae conidia was reduced to one-eightieth of its original volume at $45{ }^{\circ} \mathrm{C}$ under reduced pressure, and samples were then taken to dryness in scintillation vials containing $\mathrm{I} \cdot 0 \mathrm{ml}$ of $0.3 \%(\mathrm{w} / \mathrm{v})$ thimerosal solution to prevent microbial activity. Radioactivity in spores and exudates was determined in scintillation fluid (Bray, 1960) with a Packard Tri-Carb spectrometer.

Aseptic procedures were used unless otherwise indicated. All experiments were run in duplicate and were repeated at least once.

\section{RESULTS}

Effect on germination of salt solutions in the leaching system

Pfeffer's solution and 0.025 M-phosphate buffer were as effective as water in suppressing the germination of unwashed $C$. victoriae conidia in the leaching system (Table I). Subsoil extract was slightly less effective. None of these solutions was more stimulatory than water in the non-leached controls. Therefore, a deficiency of mineral salts did not seem to limit germination in the leaching system.

\section{Exudation from spores and sclerotia under nutrient stress}

${ }^{14} \mathrm{C}$-labelled conidia of two nutrient-independent fungi, $C$. victoriae and $\mathrm{Cu}$. lunata, and one nutrient-dependent fungus, $T$. basicola, were incubated alternately on sand leached with buffer and on buffer-saturated sand without leaching. Approximately twice the amount of radioactivity was exuded from leached as from non-leached conidia, with the greatest losses occurring early (Table 2). Similar results were obtained with the nutrient-independent sclerotia of $S$. cepivorum. These results were confirmed when ${ }^{14} \mathrm{C}$-labelled conidia of $C$. victoriae were leached continuously in the model system for $96 \mathrm{~h}$ and the leachings collected in $10 \mathrm{ml}$ portions with a fraction collector. Over $90 \%$ of the radioactivity exuded was recovered in the leachings after only $12 \mathrm{~h}$ (Fig. I). Exudation after $24 \mathrm{~h}$ continued at a very low but nearly constant rate. Nearly 10 \% of the 65000 c.p.m. in the conidia initially was recovered in the leachings over the $96 \mathrm{~h}$ period of leaching.

In the light of the very rapid loss of spore constituents, the effect of spore washing on germination was determined. Membrane filters bearing washed and unwashed conidia of C. victoriae were incubated for $\mathbf{1 2} \mathrm{h}$ on natural soil or on sand leached with water. During leaching, washed conidia did not germinate and the germination of unwashed conidia was $9 \%$, the difference being statistically significant [least significant difference, LSD $(P=0.05)=7.5]$; neither germinated when incubated on soil. These results suggest that washing causes the conidia to be slightly more sensitive to inhibition in the leaching system.

\section{Effect of extended exposure to nutrient stress on germination}

Conidia of $C$. victoriae were incubated on natural soil or in the leaching system for various periods up to 56 days. The treated conidia were subsequently incubated in buffer or on PDA for an additional $\mathrm{I} 2 \mathrm{~h}$ to assess their nutrient-independence and viability, respectively. Germination in buffer was decreased from $88 \%$ to about $60 \%$ after only $\mathrm{I} 2 \mathrm{~h}$ incubation on soil or the leaching system (Fig. 2). By 7 days almost all the conidia had become dependent on exogenous nutrients, whereas viability did not begin to decrease significantly until after 2 I days. Similar results were obtained for conidia of $C$. sativus, except that their viability began decreasing several days after conversion to the nutrient-dependent state. 
Table I. Germination of unwashed $C$. victoriae conidia incubated for $12 h$ on sand undergoing leaching with various media, on sand saturated with the same media without leaching, on loam soil, or on PDA

$\begin{array}{lcc}\quad \text { Medium } & \text { Leaching* } & \text { Germination }(\%) \dagger \\ \text { Distilled water } & + & 27 \\ & - & 77 \\ \text { Phosphate buffer } & + & 20 \\ & - & 70 \\ \text { Pfeffer's solution } & + & 29 \\ \text { Subsoil extract } & - & 80 \\ & - & 40 \\ \text { Loam soil } & & 8 \mathrm{I} \\ \text { Potato-dextrose agar } & 12 \\ \text { * Rate of flow was } 75 \mathrm{ml} / \mathrm{h} \text {; +, with leaching; -, without leaching. } \\ \dagger \text { LSD }(P=0.05)=\mathrm{I} 6 .\end{array}$

Table 2. Exudation of ${ }^{14} \mathrm{C}$ from conidia of three fungi incubated alternately on sand undergoing leaching with phosphate buffer and on buffer-saturated sand without leaching

$\begin{array}{ccccc}\begin{array}{c}\text { No. of } \\ \text { incubation } \\ \text { periods* }\end{array} & \text { Leaching } \dagger & \text { C. victoriae } & \text { Cu. lunata. } & T \text {. basicola } \\ \text { I } & + & 341 & 96 & 81 \\ 2 & - & 113 & 44 & 41 \\ 3 & + & 215 & 78 & 73 \\ 4 & - & 79 & 45 & 52 \\ 5 & + & 119 & 59 & 61 \\ 6 & - & 53 & 53\end{array}$

\section{Exudates from fungal spores as germination stimulants}

Exudates collected from conidia contained amino compounds and carbohydrates including glucose. Conidia of $T$. basicola exuded only $0.16 \mu \mathrm{g}$ glucose equivalents of carbohydrates/ $10^{6}$ spores during $20 \mathrm{~h}$ of incubation, whereas $C$. victoriae lost over $95 \mu \mathrm{g}$ in $\mathrm{I} \cdot 5 \mathrm{~h}$, and $\mathrm{Cu}$. lunata about $4.3 \mu \mathrm{g}$ in $3.0 \mathrm{~h}$. Corresponding values for equivalent spore volumes (Steiner \& Lockwood, 1969) were $7.6 \times 10^{-4}, \mathrm{I} \cdot 5 \times 10^{-2}$ and $4.2 \times 10^{-3} \mu \mathrm{g}$ glucose equivalents $/ \mathrm{mm}^{3}$ spores. Glucose accounted for approximately $30 \%$ of the carbohydrates in the exudates of $C u$. lunata and T. basicola, and more than $90 \%$ for $C$. victoriae. Exudation of amino compounds, as glycine equivalents, was one-sixth to one-half that of the carbohydrates for each of the three fungi.

To determine directly whether substances exuded by spores could stimulate germination, conidia were leached with the following media: exudate collected from conidia of $C$. victoriae, a dilute nutrient solution (per litre: glucose, $524 \mu \mathrm{g}$; glycine equivalents of casein hydrolysate, $84 \mu \mathrm{g}$ ), and water. Nutrient solution concentrations corresponded to those of carbohydrates and amino compounds in the natural exudate. Exudate from conidia of C. victoriae increased germination in $\mathrm{I} 2 \mathrm{~h}$ from $\mathrm{I} 5 \%$ when leached with water, to $42 \%$; the dilute nutrient solution raised germination to $50 \%$ (Table 3 ). The decrease in the percentage of spores bearing germ tubes after $12 \mathrm{~h}$ of leaching with exudate or the nutrient solution was 


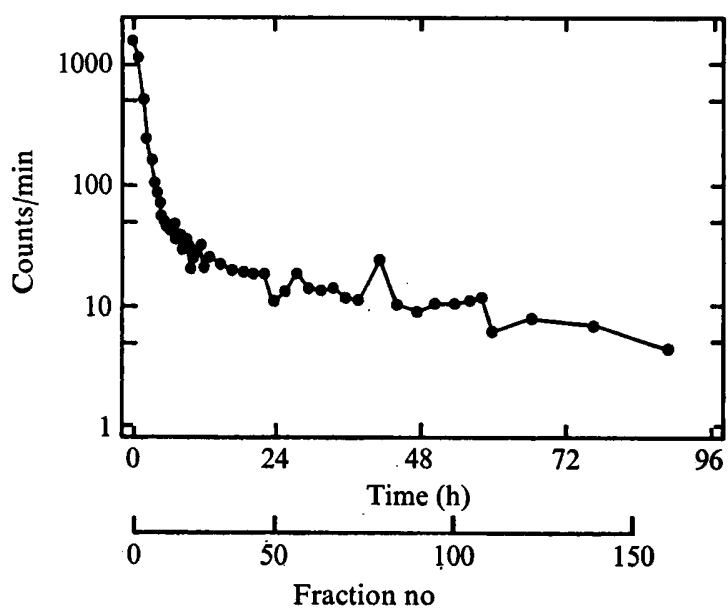

Fig. I

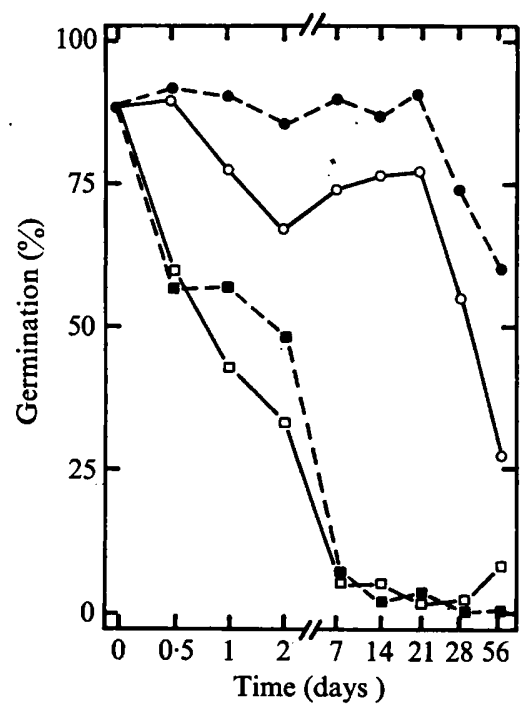

Fig. 2

Fig. I. Exudation of ${ }^{14} \mathrm{C}$-labelled compound from unwashed conidia of $C$. victoriae incubated on leached sand for $96 \mathrm{~h}$. Leaching rate was $50 \mathrm{ml} / \mathrm{h}$. Leachings were collected in successive $10 \mathrm{ml}$ fractions, several of which were combined for determination of radioactivity, after $12 \mathbf{h}$.

Fig. 2. Germination of $C$. victoriae conidia after $\mathrm{I} 2 \mathrm{~h}$ on $(\square, \square)$ phosphate buffer or $(\boldsymbol{\theta}, 0)$ PDA, after an initial incubation on soil (closed symbols) or on leached sand (open symbols) for up to 56 days. Note: the time scale has been compressed for higher values.

Table 3. Germination of C. victoriae conidia on soil, on sand undergoing leaching with water, natural exudate from conidia of $C$. victoriae, or a dilute nutrient solution, and on sand saturated with each of the three media but without leaching

\begin{tabular}{|c|c|c|c|c|c|}
\hline \multirow[b]{2}{*}{ Medium } & \multirow[b]{2}{*}{ Leaching* } & \multicolumn{4}{|c|}{ Germination (\%) } \\
\hline & & $6 \mathrm{~h}$ & $12 \mathrm{~h}$ & $24 \mathrm{~h}$ & $48 \mathrm{~h}$ \\
\hline Water & 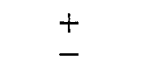 & $\begin{array}{l}\text { I3 } \\
79\end{array}$ & $\begin{array}{l}\text { I5 } \\
78\end{array}$ & $\begin{array}{l}\text { I3 } \\
79\end{array}$ & $\begin{array}{l}12 \\
54\end{array}$ \\
\hline Natural exudate & $\stackrel{+}{-}$ & $\begin{array}{l}26 \\
8 I\end{array}$ & $\begin{array}{l}42 \\
77\end{array}$ & $\begin{array}{l}33 \\
80\end{array}$ & $\begin{array}{l}\text { II } \\
64\end{array}$ \\
\hline Nutrient solution & $\stackrel{+}{-}$ & $\begin{array}{l}36 \\
8 \mathrm{I}\end{array}$ & $\begin{array}{l}50 \\
82\end{array}$ & $\begin{array}{l}45 \\
76\end{array}$ & $\begin{array}{l}23 \\
68\end{array}$ \\
\hline Soil & & 2 & I & 4 & 2 \\
\hline $\operatorname{LSD}(P=0.05)$ & & 14 & 15 & 9 & 14 \\
\hline
\end{tabular}

due to germ-tube lysis. Apparently the stimulatory substances in exudates were sufficient to promote germination, but not to maintain germ tube growth.

Germination was likewise stimulated when $C$. victoriae conidia were leached with exudate from $\mathrm{Cu}$. lunata conidia or its corresponding nutrient solution, indicating the non-specificity of the stimulatory constituents of spore exudates. Increases in germination, over that with water, also occurred when $\mathrm{Cu}$. lunata conidia were leached with their own exudate or that of C. victoriae.

When conidia of $C$. victoriae which had been first converted to nutrient dependence by incubation on soil or the leaching system for I4 to 2I days, were subsequently incubated on 
membranes floated on concentrated leachate from ${ }^{14} \mathrm{C}$-labelled $C$. victoriae conidia, they gave 52 to $73 \%$ germination in $12 \mathrm{~h}$, compared with $10 \%$ germination for similar spores incubated on buffer-saturated sand. During the incubation period on concentrated exudate, half to three-quarters of the radioactivity initially available in the exudate was detected in the conidia.

\section{DISCUSSION}

These results confirm the findings of others that germination of nutrient-independent fungal propagules is suppressed when the diffusion gradient away from them is steep. Apparently, loss of propagule exudates beyond a given critical rate, as occurs in the leaching system, prevents germination, whereas it proceeds in the non-leached controls where the rate of exudation is less, and the exuded materials remain in the environment. Most of the exuded materials were rapidly lost. Jackson \& Knight (1973) reported a similar rapid loss of glucose from conidia of $C$. sativus during leaching. The source of the initial flush of exuded materials is unknown. It may represent substances accumulated on the surface of the spore during its formation, with subsequent losses representing endogenous reserves. Alternatively, the exuded materials may represent soluble products used by the spore in germ-tube synthesis and derived from an insoluble reserve. Under conditions of sufficient diffusion stress, e.g. microbial activity in soil, these materials may be lost at such a rate as to prevent germination.

The conversion of $C$. victoriae and $C$. sativum conidia from a state of nutrient independence to one of dependence by exposure to soil or the leaching system, suggests that endogenous reserves were nc longer sufficient to permit germination. Conidia of Neurospora tetrasperma (Ko \& Lockwood, 1967) and Botrytis cinerea (Sztejnberg \& Blakeman, 1973), when leached in a system similar to the one used in this study, became dependent on exogenous nutrients for germination within 12 and $24 \mathrm{~h}$, respectively. However, chlamydospores of $T$. basicola (Tsao \& Hawthorne, 1970) remained nutrient-independent after unspecified 'intense' leaching or 'prolonged' incubation on soil. The formation of resistant chlamydospores may be one means whereby the loss of nutrients, and thus nutrient independence and propagule viability, is delayed. Formation of chlamydospores within the conidia of C. victoriae or C. sativus may have a similar function, but was not observed in this work. The time required for conversion to nutrient dependency may depend on the type of propagule, the amount of endogenous reserves that must be depleted and the intensity of the nutrient sink.

The stimulation by exudates of germination of $C$. victoriae conidia previously converted to a nutrient-dependent condition, and the accumulation of these exudates by the conidia, further indicate the importance of exudates in spore germination. Uredospores of Puccinia graminis f.sp. tritici also utilized exuded carbohydrates during germination (Daly, Knoche \& Wiese, 1967). The stimulation of germination by exudates is apparently non-specific, since two species germinated equally whether leached in their own or the other's exudates. Stimulation of germination during leaching with a dilute solution of glucose and amino acids, but not of mineral salts, indicates that the germination stimulants may be energy-yielding nutrients. Similar results were obtained by Ko \& Lockwood (1967) and Sztejnberg \& Blakeman (1973). However, mineral salts alone were sometimes sufficient to stimulate germination of conidia of $B$. cinerea made nutrient-dependent by previous leaching with water or a salt solution (Sztejnberg \& Blakeman, 1973). The results support the proposal of Ko \& Lockwood (1967), that exudates of nutrient-independent propagules required for germination may become unavailable through microbial utilization, resulting in fungistasis.

Journal article No. 7125 from the Michigan Agricultural Experiment Station. 


\section{REFERENCES}

Bray, G. A. (1960). A simple efficient liquid scintillator for counting aqueous solutions in a liquid scintillation counter. Annals of Biochemistry 1, 279-285.

DALY, J. M., KNOCHE, H. W. \& WIESE, M. V. (1967). Carbohydrate and lipid metabolism during germination of uredospores of Puccinia graminis tritici. Plant Physiology 42, 1633-1642.

EmmatTy, D. A. \& Green, R. J., Jun. (1969). Fungistasis and behaviour of microsclerotia of Verticillium albo-atrum in soil. Phytopathology 59, 1590-1595.

Hsu, S. C. \& Lockwood, J. L. (I973). Soil fungistasis: behaviour of nutrient-independent spores and sclerotia in a model system. Phytopathology 63, 334-337.

JACKsON, R. M. \& KNIGHT, R. A. (I973). Conidial germination of Cochliobolus sativus on soil and under artificial nutrient stress. In Abstracts of Papers, Second International Congress of Plant Pathology. Minneapolis: University of Minnesota.

Ko, W. H. \& Lockwood, J. L. (1967). Soil fungistasis: relation to fungal spore germination. Phytopathology 57, 894-90I.

LingaPPA, B. T. \& Lockwood, J. L. (I964). Activation of soil microflora by fungus spores in relation to soil fungistasis. Journal of General Microbiology 35, 21 5-227.

LukENs, R. J. (1960). Conidial production from filter paper cultures of Helminthosporium vagans and Alternaria solani. Phytopathology 50, 867-868.

Pringle, R. B. \& Scheffer, R. P. (1963). Purification of the selective toxin of Periconia circinata. Phytopathology 53, 785-787.

STEINER, G. W. \& Lockwood, J. L. (1969). Soil fungistasis: sensitivity of spores in relation to germination time and size. Phytopathology 59, 1084-1092.

SztejnberG, A. \& Blakeman, J. P. (1973). Studies on leaching of Botrytis cinerea conidia and dye absorption by bacteria in relation to competition for nutrients on leaves. Journal of General Microbiology 78, I 5-22.

Tsao, P. H. \& Hawthorne, B. T. (I 970). Soil fungistasis, soil amendments, lysis, and biological control of Thielaviopsis basicola. Proceedings, Seventh International Congress of Plant Protection, Paris, pp. 534535.

Yoder, D. L. \& Lockwood, J. L. (1973). Fungal spore germination on natural and sterile soil. Journal of General Microbiology 74, 107-I 17. 